welches die $\mathrm{C}_{20}$-Phytosphingosin-Anhydro-Base $(\mathrm{III})(n=15)$ enthält $\left.{ }^{7}\right)$.

I

$$
\begin{aligned}
\mathrm{CH}_{3}\left(\mathrm{CH}_{2}\right)_{2}-\mathrm{CH}-\mathrm{CH}-\mathrm{CH}-\mathrm{CH}_{2} \mathrm{OH} \\
\stackrel{\mathrm{OH}}{\mathrm{OH}} \mathrm{NH}-\mathrm{CO}-\mathrm{CH}\left(\mathrm{CH}_{2}\right)_{23} \mathrm{CH}_{3}
\end{aligned}
$$

$\mathrm{OH}$

II

$$
\begin{gathered}
\mathrm{CH}_{3}\left(\mathrm{CH}_{\mathrm{2}}\right)_{15}-\mathrm{CH}-\mathrm{CH}-\mathrm{CH}-\mathrm{CH}_{2} \\
\text { OH } \mathrm{NH}-\mathrm{CO}-\mathrm{CH}\left(\mathrm{CH}_{2}\right)_{23} \mathrm{CH}_{3} \\
\mathrm{OH}
\end{gathered}
$$

In der letzten Zeit beschäftigten wir uns mit synthetischen Versuchen auf diesem Gebiet. Wir haben zuerst eine partielle Synthese von II durchgeführt. Als Ausgangsmaterial diente die aus natürlichem II leicht zugängliche Cerebrin-AnhydroBase (C $C_{20}$-Phytosphingosin-Anbydro-Base) (III), welche mit 2-Acetoxyhexakosansäurechlorid in Ätherlösung und in Gegenwart von Chinolin acyliert worden war. Die zu diesem Zweck notwendige 2-Oxyhexakosansäure wurde durch die hydrolytische Spaltung von I hergestellt. Die bei der Reaktion erhaltene Monoacetyl-Verbindung von II wurde über das Diacetyl-Derivat (IV) vom Schmp. 89 bis $90^{\circ},[\alpha]_{D}^{26}+17,3^{\circ}$,

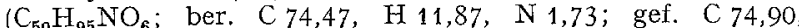
$\mathrm{H}_{11}, 54$, N 2,24) gereinigt. Die Abspaltung von Acetylgruppen mit methanolischem Kaliumhydroxyd lieferte II in guter Ausbeute. Das synthetische Produkt, welches aus Athanol umkristallisiert wurde, zeigte den Schmp. 115 bis $116^{\circ}$ und $[\alpha]_{\mathrm{D}}^{27}+14,2^{\circ}\left(\mathrm{C}_{46} \mathrm{H}_{91} \mathrm{NO}_{4}\right.$; ber. $\mathrm{C} 76,50, \mathrm{H} 12,70, \mathrm{~N} 1,90$ gef. $\mathrm{C} 76,65, \mathrm{H} 12,88, \mathrm{~N} 2,27)$. Beide Substanzen (II und IV) ließen sich nach Mischschmelzpunkt, spezifischer Drehung und IR-Spektren in Nujol mit den gleichen Präparaten natürlicher Herkunft identifizieren. Damit ist die erste partielle Synthese eines Phytosphingolipoidanteils mit der Ceramidstruktur er reicht.

Die ausführliche Veröffentlichung dieser Arbeit erscheint demnächst an anderer Stelle.

Institut "Ruder Bošković", Biochemische Abteilung, Zagreb, Kroatien, Jugoslavien

$$
\text { M. ProšteniK und B. Ries-Lešić }
$$

Eingegangen am 25. März 1960

*) XIV. Mitt. über Sphingolipoide. XIII. Mitt.: Rres-Lešrć,B., 1. M. Proštenik: Croat. chem. Acta 32, 17 (1960).

1) Reindel, F.: Liebigs Ann. Chem. 480, 76 (1930). - ${ }^{2}$ ) CARTer, H.E., W.D. Celmer, W.E.M. Lands, K.I. Muelier U. H. H. Tomizawa: J. Biol. Chem, 206, 613 (1954). -3) Proštenik, M., u. N. Z. Stanaćev: Chem. Ber. 91, 961 (1958). - O) Oda, T., u. H. Kamiya: Chem. Pharm. Bull. Japan 6, 682 (1958). - 5) SweELEY, C.C.: J. Lipid Res. 1, 40 (1959). - - 6) Reindel, F., A. WeICKinann, S. Picard, K. Luber u. P. Turula: Liebigs Ann. Chem. M44, 116 (1940). - 3) Proštenik, M., B. MAJHOFER-OREŠČANIN

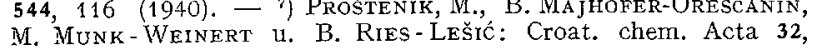
$11(1960)$.

\section{Functional Organo-boron Compounds}

At the time of the publication of the synthesis of (II) ${ }^{1}$ ), we had prepared another type of boron-containing purine analog (I) wherein boron is incorporated in the imidazole ring of the purine system. In the course of our studies, we have also prepared the analogous pyridoboradiazole (III).<smiles></smiles>

III

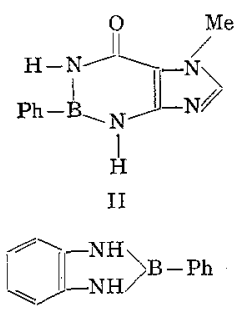

IV
5,7-Diketo-4,6-dimethyl-2 - pheny1 - $1 \mathrm{H}$-2,3,4, 5,6,7 - hexahydropyrimido-[4.5-d] [2.1.3]boradiazole (I) was prepared (90\% yield) by condensation of 1,3-dimethyl-5,6-diaminouracil with benzeneboronic anhydride as a heterogeneous system in refluxing dry toluene, the water formed being removed azeotropically. No good solvent for recrystallizing (I) was found. Recrystallization from butanone, acetonitrile and dimethyl formamide did not raise the melting point and resulted in appreciable loss by decomposition. (I) isolated from the reaction mixture was a pale yellow powder, m.p. (evacuated capillary) 268 to $275^{\circ}$ dec. Anal. Calcd. for $\mathrm{C}_{12} \mathrm{H}_{12}$ $\mathrm{BN}_{4} \mathrm{O}_{2}: \mathrm{C}, 56 \cdot 28 ; \mathrm{H}, 5 \cdot 12 ; \mathrm{N}, 21.88 ; \mathrm{B}, 4 \cdot 23$. Found: C, 56.48 ; $\mathrm{H}, 5 \cdot 10 ; \mathrm{N}, 21 \cdot 69 ; \mathrm{B}, 4 \cdot 32$. (I) is unstable in water and methanol. Exposed to air (I) turns pink, although the melting point and $I$. $R$. spectrum remain unchanged.

Condensation of 2,3-diaminopyridine with benzeneboronic anhydride in refluxing toluene gave a $93 \%$ yield of crude 2,3-dihydro-2-phenyl-1 H-pyrido[2.3-d] [2.1.3]boradiazole (III), a white crystalline solid (recrystallized from toluene), m.p. $221 \cdot 5$ to $222 \cdot 5^{\circ}$. Anal. Calcd. for $\mathrm{C}_{11} \mathrm{H}_{10} \mathrm{BN}_{3} ; \mathrm{C}, 67 \cdot 74$; $\mathrm{H}, 5 \cdot 17 ; \mathrm{N}, 21 \cdot 55 ; \mathrm{B}, 5.55$. Found: $\mathrm{C}, 67.65 ; \mathrm{H}, 4 \cdot 75 ; \mathrm{N}, 21.51$; $\mathrm{B}, 5 \cdot 80$. (III) is also unstable in water and methanol.

Infraved spectral data (determined in $\mathrm{KBr}$ plates). The infrared spectra of both (I) and (III) are quite different from the spectra of equimolar mixtures of the two components used to prepare each compound. In the spectra of both (I) and (III), two peaks at 2.95 to 3.15 microns are consistent with the presence in each compound of two unsymmetrically substituted NH-functions. The spectrum of the symmetrical compound (IV $)^{2}$ ) shows only one peak in this range. Characteristic peaks at 6.95 and 9.7 to 9.9 microns in the spectra of (I), (III), (IV) and phenylboronic anhydride suggest to us the presence of $\mathrm{B}-\mathrm{C}$ (aromatic) bonds. A peak at 9.0 to 9.15 microns in the spectra of the boradiazoles (I, III, IV) may be characteristic of $B-N$ bonds. A peak at 6.5 microns in the spectrum of (I), which does not appear in the spectra of (III), (IV) and phenylboronic anhydride, may be characteristic of boradiazoles derived from diaminouracils.

The ultraviolet spectrum of (I) in acetonitrile was different from that of an equimolar mixture of dimethyl-diaminouracil and phenylboronic anhydride, but within four hours the spectrum was quite similar to that of the mixture. After the solutions had stood for a week, the two spectra were identical. This confirmed the instability of (I) in acetonitrile.

This is a preliminary communication of our work which, in part, will be the basis of a M. S. thesis to be presented by A. D. S. to the University of Cincinnati, 1960.

Department of Chemistry, University of Cincinnati, Cincinnati 21, Ohio

HANS ZiMMER

Department of Organic Research, The William S. Merrell Company, Cincinnati 15, Ohio

Arthur D. Sill und EDwin R. ANdrews

Eingegangen am 30. Mai 1960

1) Chisick, S.S., M.J.S. Dewar and P.M. Maitlis: J. Amer. Chem. Soc. 81, 6329 (1959). - 2) Letsinger, R. L., and S. B. HA Milton: J. Amer. Chem. Soc. 80, 5411 (1958); b) Dewar, M. J.S. V.P. KubBa and R. Pettit: J. Chem. Soc. [London] 3076 (1958)

\section{Polyine als Inhaltsstoffe der Arnikawurzel}

Bei der Fraktionierung eines Pentan-Extraktes aus der Wurzel von Arnica montana L. durch Chromatographie über Aluminiumoxyd (Merck, stand. nach BRockMANN) wurden vier Fraktionen (zusammen etwa $0,2 \%$ des Gesamtextraktes) erhalten, die im UV folgende Maxima besitzen:

1. $\lambda_{\max } 410 ; 378 ; 352 ; 328 ; 308 ; 286 ; 272 \mathrm{mu}$ (in Pentan). 2. $\lambda_{\max } 401 ; 371 ; 345 ; 322,302 \mathrm{~m} \mu$ (in Pentan)

3. $\lambda_{\max } 399 ; 369 ; 343 ; 320 \mathrm{~m} \mu$ (in Pentan $-1 \%$ Benzol). 4. $\lambda_{\max } 390,5 ; 361 ; 337 ; 315,5 ; 288 \mathrm{~m} \mu$ (in Pentan $-1 \%$ Benzol).

Es dürfte sich bei den vier Substanzen um Polyacetylene handeln, und zwar scheint Verbindung 1 mit dem von N.A. SöRENSEN u. Mitarb. ${ }^{1}$ ) aus verschiedenen Spezies der Tribus Inuleae und Heliantheae isolierten, als ,410-Pigment" bezeichneten Tridecaen-(1)-pentain-(3-5.7.9.11) identisch zu sein. Verbindung 2 besitzt die gleichen UV-Maxima wie das von den obigen Autoren ${ }^{1}$ ) in Helipterum-Arten aufgefundene "400,5-Pigment", dessen Konstitution noch unbekannt ist. Ebenfalls noch unbekannter Struktur ist das von denselben Autoren ${ }^{1}$ ) in Helipterum-Arten aufgefundene, ,398,5-Pigment", dessen UV-Maxima mit den Maxima der aufgefundenen Verbindung 3 übereinstimmen.

Das UV-Spektrum der Verbindung 4 ist identisch mit dem Spektrum des En-in-Kohlenwasserstoffes Tridecadien-(1.11)tetrain-(3.5.7.9). Dieser Kohlenwasserstoff wurde von J.S. SöRENSEN und N.A. Sörensen ${ }^{2}$ ) in Coreopsis-Arten und von F. BohlmaNn u. Mitarb. ${ }^{3}$ ) in Centaurea-Arten aufgefunden. 